\title{
The Influence of Village Fund and Its Allocation on Poverty Levels in Isolated Areas in Batulanteh District
}

\author{
Fitriah P.Cita* \\ Faculty of Economics and Business \\ Sumbawa University of Technology \\ Sumbawa, Indonesia \\ fitriah.permata.cita@uts.ac.id
}

\author{
Sari Nurhanitah \\ Faculty of Economics and Business \\ Sumbawa University of Technology \\ Sumbawa, Indonesia \\ sarinurhanita@gmail.com
}

\author{
Fahlia Fahlia \\ Faculty of Economics and Business \\ Sumbawa University of Technology \\ Sumbawa, Indonesia \\ fahlia@uts.ac.id
}

\author{
Diah A.Hasri \\ Faculty of Economics and Business \\ Sumbawa University of Technology \\ Sumbawa, Indonesia \\ diah.anggeraini.hasri@uts.ac.id
}

\author{
M.Rafi'I Sanjani \\ Faculty of Economics and Business \\ Sumbawa University of Technology \\ Sumbawa, Indonesia \\ muhammad.rafii.sanjani@uts.ac.id
}

\begin{abstract}
This study was aimed at analyzing the influence of the Village Fund (DD) and Village Fund Allocation (ADD) on the level of poverty of people in isolated areas in Batulanteh District. The data used in this research were the Poverty Rate, Village Fund and Village Fund Allocation, in which the data were Cross-section data with Time Series from 2017-2019 with research focusing on six villages. The analytical tool used in this study was multiple regression with panel data. The form of Panel Data regression results with the chosen model was the Common effect, with the results of data processing showing the coefficient value of the Village Fund and Village Fund Allocation significantly influence towards the level of poverty. Hence, the Village Fund variable and Village Fund Allocation variable simultaneously influence the level of Poverty in Batulanteh District.
\end{abstract}

Keywords - Village Fund, Poverty Levels

\section{INTRODUCTION}

Indonesia is a country with a population of 269 million or 3.49 which is the fourth most populous country in the world after China, India and the United States. The increasing population growth every year will affect the problem of poverty. Poverty is a major problem that is always faced by every country, especially in developing countries like Indonesia.

Sumbawa Regency is one of the regions in West Nusa Tenggara Province that still has large number of people living under poverty. Based on data from the Central Bureau of Statistics, the number of poor people reached 63.76 thousand in 2018 and the largest distribution of the number of poor people was still concentrated in rural areas.

The distribution of the poor is still concentrated in rural areas according to the Central Bureau of Statistics (BPS). One of them is Sumbawa regency which has 24 districts and still has isolated districts such as the Batulanteh district which consists of 6 villages. Batulanteh district itself is a disadvantaged region with the highest number of poverty rates. Most residents in each village in Batulanteh district work as farmers [1].
A government program which is called Nawa-Cita contains a program aimed at reducing poverty in rural areas by starting to develop Indonesian territory starting from the suburbs. One of the programs is the Village Fund, which began in 2015. This fund is given in a certain amount to each village in each district to overcome the gap between residents in the village and city.

The Village Fund is an obligation of the Central Government to allocate the transfer budget to the Village in the state budget as a form of recognition and appreciation of the Government to the Village. The priority of the use of village funds is regulated through a Regulation of the Minister of Village, Development of Disadvantaged Regions, and Transmigration. With this budget, villages have the opportunity to develop the economy of their communities and areas that are still isolated need to be supported.

\section{LITERATURE REVIEW}

Village is an area with a population of approximately 2,500 [2]. Law No. 6 of 2014 concerning Villages outlines that is basically the allocation of Village Funds aims to improve the welfare of village communities. Fund Allocation (ADD) is the obligation of the Regency or City Government to allocate a budget for the Village taken from the Revenue Sharing Fund (DBH) and the General Allocation Fund (DAU) which is part of the Fiscal Balance Transfers [3]. Based on Law No. 24 of 2004, poverty is the socio-economic condition of a person or group of people whose basic rights are not fulfilled to maintain and develop a dignified life. Underdeveloped areas are regencies that are relatively less developed compared to other regions on a national scale, and have relatively disadvantaged populations. 


\section{METHODS}

\section{A. Data and Data Sources}

The data of this study were secondary data from the Office of Community and Village Empowerment Agency, Village Government and the Social Service Office of Sumbawa Regency. The research was located in Batulanteh District which consists of 6 villages. Techniques and Methods for Analyzing Data of Panel Data Regression. According to [4], panel data regression is a regression technique that combines time series data with cross section data. Meanwhile, [5] states that there are several methods commonly used in estimating panel data, namely pooling least square (common effect), fixed effect approach, and random effect approach:

\section{B. Classic Assumption Test}

\section{Normality Test}

Normality test aims to test whether the sample used has a normal distribution or not. If the probability is $>0.05$ then the distribution of the regression model is normal. If the probability is $<0.05$ then the distribution of the regression model is not normal.

\section{Multicollinearity Test}

Multicollinearity test results can be used to test the regression model, whether or not there is a correlation between independent variables, if the value is below 0.8 , multicollinearity does not occur [6].

\section{Heteroscedasticity Test}

If the probability value is greater than the level of alfha $(\alpha)$ $5 \%$, it means heteroscedasticity does not occur.

\section{Autocorrelation Test}

To detect the existence of autocorrelation, it can be done by doing the Durbin-Watson test.

\section{Hypothesis Testing}

Determination Analysis (R2)

Determination analysis in multiple linear regression is used to determine the percentage contribution of the influence of the independent variables simultaneously on the dependent variable [7].

\section{F-Statistic Test}

The $F$ test is used to determine the effect of all independent variables, whether the regression model together has an influence on the dependent variable tested at a significant level of $0.05(5 \%)$. The test criteria for the $\mathrm{F}$ test are, if the F-statistic value is lower than $0.05(5 \%)$, it can be concluded that all the independent variables studied together can influence the independent variable. If F-count $<$ F-table, then Ho is rejected and $\mathrm{Ha}$ is accepted. If F-count $>$ F-table, then Ho is accepted and $\mathrm{Ha}$ is rejected. If F-count $<$ F-table, then Ho is rejected and $\mathrm{Ha}$ is accepted. This means that the independent variables jointly affect the dependent variable.

\section{$t$-Statistic Test}

$\mathrm{t}$-statistic test is a test aiming at finding out whether each of the multiple regression coefficients has a significant effect or not on the dependent variable by assuming the other independent variables are constant. The steps taken in testing are by arranging the null hypothesis (H0) and the alternative hypothesis (Ha) with the real level $(\alpha)$ in which the standard value of $\alpha$ commonly used is $5 \%$. The conclusion is made by looking at the value of $\operatorname{sig} \alpha(5 \%)$ with the following conditions:

a) If prob $>0.05$ then $\mathrm{H} 0$ is accepted

b) If prob $<0.05$ then $\mathrm{H} 0$ is rejected.

\section{RESULTS AND DISCUSSIONS}

TABLE I. LAGRANGE MUlTIPLIER TEST

\begin{tabular}{|c|c|c|c|}
\hline Test Summary & Chi-Sq. Statistic & Chi-Sq. d.f. & Prob. \\
\hline Cross-section random & 8.996098 & 2 & 0.0027 \\
\hline
\end{tabular}

From the results obtained above, for the Cross-section randow probability value of 0.0027 whose value is smaller than $a=0.05$, it can be concluded that the common effect model is more appropriate than the random effect model. After getting the best model, the next step was to conduct the classic assumptions test:

Normality Test

If Jarque-Bera (JB) $>0.05$, the data is normally distributed. After conducting the test, it could be seen from the Probability value, it was $0.8475850>0.05$, then the data was normally distributed in the normality test.

\section{Multicollinearity Test}

The multicollinearity assumption test produced a correlation value between the variables of -0.011612 and it shows that if $-0.011612<0.8$ then it means there is no multicollinearity. Thus, it can be concluded that there is no heteroscedasticity in the data.

\section{Autocorrelation Test}

The autocorrelation test results were 3,620669>DU 0.9331, then $\mathrm{H} 0$ was accepted and Ha was rejected. Thus, it can be concluded that there is no negative autocorrelation.

TABLE II. MOdEL EFFECT Estimation Results

\begin{tabular}{|c|c|c|c|}
\hline Variable & Coefficient & t-statistic & Probabili \\
$\mathbf{t}$ \\
$\mathbf{y}$
\end{tabular}

\section{t-Statistic Test}

The variable village fund (X1) had a t-count of 2.25791 and a probability value of 0.0393 . From the results of the study, it was obtained a probability value of $0.0393<0.05$. Partially, this value has a significant effect on poverty levels. The variable allocation of village funds (X2) had a tcount of 0.913207 and a probability value of 0.3756 . The research result obtained was the probability value of 0.3756 $>0.05$. Partially, this value has no significant effect on poverty levels. 


\section{F-Statistic Test}

From the Village Fund variable and the Village Fund Allocation variable, the F-statistic value obtained was 2.942508, while the F-table was 3.68. F-table value based on the magnitude was $5 \%$. Thus, the F-statistic is smaller than the F-table which means that the Village Fund and Village Fund Allocation simultaneously influence Poverty.

\section{Determination $R 2$ Test}

The $\mathrm{R} 2$ value of the model was 0.281782 . It means the variable of the Village Fund changed and the Village Fund Allocation only contributed to the Poverty Rate of $28 \%$, while the remainder $(72 \%)$ was contributed by other variables not observed in this study.

\section{DisCUSSIONS}

Simultaneous Effect of Amount of Village Funds and Amount of Village Fund Allocation on Poverty Level in Batulanteh District. The F-statistic value obtained was 2.942508, while the F-table was 3.68. Thus, F-statistic is smaller than F-table. Hence, these two variables affect the dependent variable (poverty).

Regarding how big the influence of the two programs on the ratio of poverty levels in Batulanteh sub-district is somewhat small. Both policies prioritize funding for infrastructure or physical development only, while for the field of community empowerment for the development of local economic potential is still somewhat invisible.

\section{CONCLUSIONS}

Partially, in this study, the variable amount of village funds did not significantly influence poverty levels in Batulanteh District in 2017-2019. Simultaneously, in this study, the variable amount of village funds and the amount of allocation of village funds significantly influenced poverty levels in Batulanteh District in 2017-2019. In the future, the government or related institutions is expected to prepare villages through strengthening the capacity of Human Resources.

For further researchers, in order to conduct research, researchers are not only to investigate at the village level, but also at the district level. Furthermore, it is expected to conduct further research related to the usefulness or influence of other variables not included in the study.

\section{REFERENCES}

[1] Badan Perencanaan Pembangunan Daerah Provinsi NTB.2018. Rencana Aksi Daerah Percepatan Pembangaunan Daerah.

[2] Paul H.Landis.2007.Tata Desa. Bandung: Mandar Maju.

[3] Sri Mulyani.2015. Formula pengalokasian Dana Desa.Dep,Keu RI : Jakarta.

[4] Basuki,Agus Tri and Prawoto,Nano.2016. Analisis Regresi Dalam Penelitian Ekonomi \& Bisnis : Dilengkapi Aplikasi SPSS \& EVIEWS. Depok: PT Rajagrafindo Persada.

[5] Widarjono, Agus. 2009. Ekonometrika Pengantar dan Aplikasinya. Yogyakarta: Ekonosia

[6] Gujarati,Damodar N.2011. Dasar-dasar Ekonomitrika :Edisi 5buku 1. Jakarta :Salemba Empat

[7] Dwi Priyatno, 2008. Mandiri Beljar SPSS (UntukAnalisis Data dan Uji Statistik). Yogyakarta: MediaKom 